\title{
Genotoxic Effects of Three Selected Black Toner Powders and Their Dimethyl Sulfoxide Extracts in Cultured Human Epithelial A549 Lung Cells In Vitro
}

\author{
Richard Gminski, ${ }^{1 *}$ Katharina Decker, ${ }^{1}$ Christina Heinz, ${ }^{1}$ Albrecht Seidel, ${ }^{2}$ \\ Mathias Könczöl, ' Ella Goldenberg, ${ }^{3}$ Bernard Grobéty, ${ }^{4}$ Winfried Ebner, \\ Reto Gieré ${ }^{3}$ and Volker Mersch-Sundermann ${ }^{1}$ \\ ${ }^{1}$ Department of Environmental Health Sciences, University Medical Center \\ Freiburg, D-79106 Freiburg, Germany \\ ${ }^{2}$ Biochemical Institute for Environmental Carcinogens, D-22927 Großhansdorf, \\ Germany \\ ${ }^{3}$ Institute of Geoscience, University Freiburg, D-79104 Freiburg, Germany \\ ${ }^{4}$ Department of Geosciences, University of Fribourg, CH-1700 Fribourg, Switzerland
}

\begin{abstract}
Until now, the adverse effects of toner powders on humans have been considered to be minimal. However, several recent reports have suggested possible significant adverse health effects from toner dust inhalation. The aim of this study was to evaluate the genotoxic potential of black toner powders in vitro. For the study of DNA damage, A549 cells were exposed to toner-powder suspensions and to their DMSO extracts, and then subjected to the comet assay and to the in-vitro cytokinesis block micronucleus test (CB-MNvit). Cytotoxic effects of the toner samples were assessed by the erythrosin B assay. Furthermore, size, shape, and composition of the toner powders were investigated. None of the three toner powders or their DMSO extracts reduced cell viability; however, they did induce DNA damage and
\end{abstract}

formed micronuclei at concentrations from 80 to $400 \mu \mathrm{g} \mathrm{cm}{ }^{-2}$, although to a varying extent. All toner powders contain considerable amounts of the pigments carbon black and magnetite $\left(\mathrm{Fe}_{3} \mathrm{O}_{4}\right)$ as well as small amounts of polycyclic aromatic hydrocarbons (PAHs). The overall results of our invitro study suggest that the investigated toner-powder samples are not cytotoxic but genotoxic. From the results of the physical and chemical characterization, we conclude that metals and metalloids as components of magnetite, or $\mathrm{PAHs}$ as components of the carbon-bearing material, are responsible for the genotoxic effects. Further research is necessary to determine the relevance of these in-vitro observations for private and occupational toner powder exposure.

\section{INTRODUCTION}

As a result of rapid progress in office and home automation, the number of instruments used for computing, information, and communication has increased steadily in developed countries. Among these are laser printers, facsimile machines, and photocopiers, which use powdered toner for printing characters and images. Thus, a substantial section of the population may currently be exposed to toner powder. Workers manufacturing the powders and technicians changing the toner cartridges or maintaining the active devices come into direct contact with considerable amounts of toner powder, and thus belong to the population groups that have frequent high exposure to toner particles. Office staff, on the other hand, is more likely to be exposed to the emissions produced by printing or photocopying rather than to the toner powder itself. Exposure to ultrafine particles (UFP, diameter $<0.1 \mu \mathrm{m}$ ) emitted from the hardcopy devices is a topic of high concern for this group [He et al., 2007; Schripp et al., 2008; Wensing et al., 2008]. Exposure to toner powder may occur via dermal routes by direct skin or eye contact, respiration by inhalation, or ingestion if toner powder is swallowed accidentally.

Toner powders consist of very small particles of a thermoplastic polymer, usually a styrene-acrylate copolymer,

*Correspondence to: Richard Gminski, Department of Environmental Health Sciences, University Medical Center Freiburg, Breisacher Str. 115b, D-79106 Freiburg, Germany.

E-mail: richard.gminski@uniklinik-freiburg.de 
which is fixed onto the paper by fusion at about $170{ }^{\circ} \mathrm{C}$. Black toner powders contain carbon black (CB) or iron $(\mathrm{Fe})$ oxides as pigments, whereas color toners additionally contain various organic pigments. In addition to these main constituents, toner powders contain various additives, such as wax and silica, and in some cases minor amounts of certain salts to control the electromagnetic properties [Lin and Mermelstein, 1994; Möller et al., 2004]. It is known that the main constituents $\mathrm{CB}$ and $\mathrm{Fe}$ oxide can contain impurities, namely polycyclic aromatic hydrocarbons (PAHs) and heavy metals [Löfroth et al., 1980; Jungnickel et al., 2002]. The diameter of individual toner particles ranges typically between 2 and $10 \mu \mathrm{m}$ [Lin and Mermelstein, 1994; Möller et al., 2004].

Until now, the health effects of toner powder on humans have been considered to be minimal. However, several reports have suggested that inhalation of toner powder may have significant adverse health effects [Tencati and Novey, 1983; Yassi and Warrington, 1988; Wieriks, 1996; Rybicki et al., 2004]. For example, Gallardo et al. [1994] reported a case of siderosilicosis, and Armbruster et al. [1996] reported a case of granulomatous pneumonitis possibly related to toner-powder inhalation at the workplace. Various people have reported to react sensitively when exposed to toner powder or toner emissions, displaying allergic reactions of the skin, the eyes, and the respiratory tract [Galun and Rubinow, 1989; Skoner et al., 1990; Zina et al., 2000; Wittczak et al., 2003]. A few epidemiological studies evaluated the effects of toner-powder exposure on respiratory health in a human population, but observed no relationship between toner-powder exposure via inhalation and the risk of adverse respiratory effects [Canham, 1996; Nakadate et al., 2006].

In animal experiments, accumulation of toner particles in the lung following long-term inhalation exposure to high toner concentrations may cause chronic inflammation and lung fibrosis but does not show increased lung tumor rates [Morimoto et al., 2005]. However, intratracheal instillation of very high doses of toner powder produced significantly increased lung tumor rates in rats [Möller et al., 2004; Pott and Roller, 2005; Mohr et al., 2006]. According to Pott and Roller [2005], these effects do not depend on the composition of the different powders, but rather on particle size or particle volume and on the potential of small particles to be deposited on the lung epithelial cells.

As stated, commercial toner powders typically contain Carbon Black. CB-particles are known to be genotoxic in in vitro and in vivo assay systems [Totsuka et al., 2009]. According to the International Agency of Research on Cancer (IARC), there is sufficient evidence in experimental animals for the cancerogenicity of $\mathrm{CB}$ and its extracts [Rosenkranz et al., 1980], but there is inadequate evidence for carcinogenicity in humans [IARC, 1996].

In this study, we investigated the in-vitro genotoxic potential of black toner powders on the A549 cell line (human alveolar epithelial-like) using the single-cell gel electrophoresis (SCGE, comet) assay and the cytokinesis block micronucleus (CB-MNvit) test. Cytotoxicity was evaluated by the erythrosin B vital exclusion assay (cell viability; used for concentration finding) and the cytokinesis block proliferation index (CBPI; cytostatic effect). The invitro model used is based on the human permanent lung cell line A549, because the alveolar epithelium is presumably the area of the respiratory tract that is most exposed to fine particles [Don Porto Carero et al., 2001; Aufderheide et al., 2003; Schwerdtle and Hartwig, 2006]. For the experiments, we chose three commercially available black toner powders designed by global market leaders for laser printers. The effects of these samples were compared to those of Dörentrup quartz DQ12, which has a genotoxic potential and may contribute to the carcinogenicity of silica in humans. Respirable quartz powder has been classified as a Group 1 carcinogen [IARC, 1997] and has been investigated in numerous studies [Donaldson and Borm, 1998; Fubini, 1998; Rimal et al., 2005; Wang et al., 2007]. Furthermore, benzo[a]pyrene $(\mathrm{B}[\mathrm{a}] \mathrm{P})$, a PAH known to be a human carcinogen, was chosen as a second positive control in the genotoxicity assays. In addition to chemical composition, other particle properties, such as size, shape, and crystal structure, may also affect the toxicity of particles, whereby the effects of chemical composition may be enhanced, reduced, or cancelled. Therefore, the toner powders and the reference particles used in this study were characterized by mineralogical and geochemical methods, including X-ray diffraction (XRD), atomic absorption spectroscopy (AAS), scanning electron microscopy (SEM), and energy-dispersive X-ray (EDX) spectroscopy.

\section{MATERIALS AND METHODS}

\section{Chemicals}

Benzo[a]pyrene (B[a]P) with a purity of $>98 \%$ (CAS No 50-32-8) was obtained from Aldrich (München, Germany). EMS with a purity of $>99 \%$ (CAS No 62-50-0) was obtained from Alfa Aesar (Karlsruhe, Germany). $\mathrm{B}[\mathrm{a}] \mathrm{P}$ and EMS solutions were made with dimethylsulfoxide (DMSO). Dulbecco's Modified Eagle's Medium (DMEM) supplemented with Low Glucose $\left(1 \mathrm{~g} \mathrm{~L}^{-1}\right)$ and with L-glutamine, FBS, trypsine, and phosphate buffered saline (PBS) were purchased from PAA Laboratories (Parsching, Austria). HEPES buffer, DMSO, cytochalasin B, erythrosin B, DAPI (4'6-diamidino2-phenylindole-dihydro-chloride) for microscopy were obtained from Sigma-Aldrich (München, Germany). HBSS (Hank's Buffered Salt Solution) was obtained from Life-Technologies (Karlsruhe, Germany). Tris buffer was obtained from Merck (Darmstadt, Germany). DQ12 (batch 6, IUF), used as a standard material, was kindly provided by Dr. Roel Schins (Environmental Health Research Institute, IUF, Düsseldorf, Germany).

\section{Toner Powders and Quartz DQ12}

Toner powders A (Kyocera TK-16H), B (Kyocera TK-17), and C (Hewlett-Packard LaserJet C4092A) used in our study are original toner powders for use with laser printers and are commercially available. According to the producers, toner powders $\mathrm{A}$ and $\mathrm{B}$ consist of styrene acrylate copolymer (50-60 wt \%), magnetite (30-40 wt \%), titanium dioxide (CAS No. 13463-67-7), (1-5 wt\%), silica (CAS No. 7631-86-9), (1$5 \mathrm{wt} \%)$ and $\mathrm{CB}(<1 \mathrm{wt} \%)$. Additionally, toner powder A contains poly 
propylene wax (CAS No. 9003-07-0) and aluminia $\left(\mathrm{Al}_{2} \mathrm{O}_{3}\right)$ (CAS No. 1344-28-1). Toner powder $\mathrm{C}$ consists of styrene acrylate copolymer (40$50 \mathrm{wt} \%)$ and magnetite (40-50 wt \%).

According to the supplier, the reference DQ12 exhibits a median diameter of 1-2 $\mu \mathrm{m}$ and contains $87 \mathrm{wt} \%$ crystalline quartz and additionally amorphous $\mathrm{SiO}_{2}$ with small contaminations of kaolinite. SEM and XRD analysis performed on DQ12 (same methods as for toner powders, see next sections) affirmed that it consists of crystalline quartz showing a size range of $80 \mathrm{~nm}$ to $3 \mu \mathrm{m}$, with two peaks around $100 \mathrm{~nm}$ and 1 $\mu \mathrm{m}$ (data not shown).

\section{Determination of Particle Size, Morphology, and Composition of Toner Powders}

The toner powders were investigated by SEM using two different procedures: first, they were dispersed as powders directly onto carbon pads mounted on the SEM sample holders. The samples were then studied in secondary electron (SE) and backscattered electron (BSE) modes using a Philips SEM (FEI XL 30 Sirion FEG). For SEM analysis (LEO FE 1525), toner-powder suspensions were prepared according to the method described below. After $20 \mathrm{~min}$ of sonication at room temperature $\left(22^{\circ} \mathrm{C}\right)$ in an ultrasonic water bath, the suspension was pipetted onto a carbon pad (Toners A and B) or directly onto the SEM sample holder (Toner C).

SE images reveal the morphologic and surface features of the individual toner particles. BSE images, on the other hand, yield qualitative chemical information, whereby the greyscale contrast depends on the mean atomic number: particles containing heavy elements, such as Fe appear bright, whereas particles containing light elements (e.g., C) appear darker. SEM has been used for imaging and energy-dispersive $\mathrm{X}$ ray spectra $(\mathrm{EDX})$, thus providing information on particle composition.

\section{Determination of the Phases in the Toner Powders}

The toner powders were studied by powder X-ray diffractometry (XRD) using a Bruker AXS D8 Advance diffractometer. The toners were dispersed onto zero-background silicon sample holders and then scanned from 2 to $65^{\circ} 2 \theta$, with a step size of $0.02^{\circ}$ and a dwell time of 6 sec/step using $\mathrm{Cu} \mathrm{K} \alpha$ radiation. The spectra were compared with the ICPDF database to identify the phases present in the toner.

\section{Determination of Metals and Metalloids in the Toner Powders and DMSO Extracts}

The bulk contents of selected metals and metalloids in the toner powders were determined by atomic absorption spectroscopy (AAS) after digesting the toner according to two different procedures: The first method comprises total digestion, accomplished in a mixture of $8 \mathrm{~mL}$ $\mathrm{HNO}_{3}, 3 \mathrm{~mL} \mathrm{HBF}_{4}$, and $1 \mathrm{~mL} \mathrm{H}_{2} \mathrm{O}_{2}$ in a microwave oven. The second procedure, consisting of digestion in aqua regia, i.e., a mixture of 1.2 $\mathrm{mL} \mathrm{HNO}_{3}, 3.6 \mathrm{~mL} \mathrm{HCl}$, and $0.5 \mathrm{~mL} \mathrm{H}_{2} \mathrm{O}$, does not dissolve the toners completely, but reveals the environmentally relevant, i.e., more soluble fraction of the toners [DEV, 2009]. Elements with low concentrations (As, $\mathrm{Pb}, \mathrm{Sb}, \mathrm{Ni}, \mathrm{Cd}$ ) were analyzed by graphite-furnace AAS (PerkinElmer 4110 ZL Zeeman), whereas elements with high concentrations (Fe, $\mathrm{Zn}$ ) were analyzed by flame AAS (Analytik Jena, AAS Vario 6) The DMSO extracts from each toner were analyzed in the same way as the digested toner dusts.

The bulk Si concentration in the toner powders was determined using a Perkin Elmer Lambda 40 UV/VIS Photometer.

\section{Determination of PAH Content in the Toner Powders}

The PAH profile analysis in toner powders was performed using a methodology described previously with some modifications [Grimmer et al.,
1997]. Briefly, an aliquot of each toner powder (5 g) was extracted with toluene in a Soxhlet apparatus for $2 \mathrm{hr}$. The extract was concentrated under vacuum and the residue was dissolved in cyclohexane. The cyclohexane phase was partitioned against dimethyl formamide/ $\mathrm{H}_{2} \mathrm{O}(9: 1)$. The dimethylformamide (DMF) phase was reextracted with cyclohexane after dilution with water (1:1). The obtained cyclohexane phase was separated and carefully concentrated under vacuum. The concentrate was chromatographed on a partially deactivated silica gel column (5 g) and after exchanging the solvent to toluene an aliquot of $1 \mu \mathrm{L}$ was analyzed by GCMS using the splitless mode. An Agilent technologies $6890 \mathrm{~N}$ apparatus was used equipped with a 7683 automated liquid sampler and connected to a 5973 network mass selective detector (MSD, Agilent Technologies). A Zebron ZB-35 MS capillary (35\% phenyl-methyl polysiloxane, $30 \mathrm{~m} \times$ $0.25 \mathrm{~mm} \times 0.25 \mu \mathrm{m}$ [film thickness], Phenomenex ${ }^{\circledR}$, Aschaffenburg, Germany) was applied for separation of the PAH profile. As internal standards the following PAH were used: $d_{8}$-naphthalene, $d_{8}$-acenaphthylene, $d_{10}$-acenaphthene, 2-fluorfluorene, $d_{10}$-phenanthrene, $d_{10}$-fluoranthene, $d_{10}$-pyrene, $d_{12}$-benzo $[a]$ anthracene, $d_{12}$-benzo[ $\left.b\right]$ fluoranthene, $d_{12}$-benzo[ $\left.a\right]$ pyrene, indeno[1,2,3-cd]fluoranthene, $d_{12}$-benzo[ghi]perylene.

\section{Preparation of Toner-Powder Suspensions}

Prior to the experiments, different amounts of each toner (60-mg toner for erytrosin B exclusion assay and comet assay, $120 \mathrm{mg}$ toner for CBMNvit assay) were suspended in $30 \mathrm{~mL}$ complete culture medium, supplemented with $2.5 \mu \mathrm{L}$ Tween 20 in a $100 \mathrm{~mL}$ glass vial. These mixtures were sonicated for $20 \mathrm{~min}$ at $40^{\circ} \mathrm{C}$ in an ultrasonic water bath (Sonorex Bandelin, Berlin, Germany) to ensure homogeneous suspensions. The suspensions were diluted in culture medium to contain a stock solution $\left(1,000 \mu \mathrm{g} \mathrm{cm}^{-2}\right)$ and this stock solution was further diluted in culture medium to obtain concentrations of $80,100,133,200$, and $400 \mu \mathrm{g} \mathrm{cm}^{-2}$ for each bioassay.

\section{Preparation of Toner-Powder (DMSO) Extracts}

Prior to use, $1 \mathrm{~g}$ of each toner powder was suspended in 5-mL DMSO in a plastic Falcon tube and vigorously shaken in a Roto-Shaker (Scientific Industries) for $24 \mathrm{hr}$ at $30^{\circ} \mathrm{C}$. The suspensions were then centrifuged two times for $10 \mathrm{~min}$ at $5,000 \mathrm{rpm}\left(21^{\circ} \mathrm{C}\right)$. The supernatant (DMSO extract) was removed and sterile $(<0.22 \mu \mathrm{m})$ filtered into another tube. The DMSO extract was further diluted in culture medium to obtain concentrations corresponding to $80,100,133,200$, and $400 \mu \mathrm{g} \mathrm{cm}^{-2}$ of toner powder for each bioassay. The final concentration of DMSO in the tissue culture medium was $0.1 \mathrm{vol} \%$.

\section{Preparation of DQ12 Particle Suspension}

Quartz DQ12 powder was weighed and baked for $16 \mathrm{hr}$ at $220^{\circ} \mathrm{C}$ to destroy endotoxins. A stock solution $\left(5 \mathrm{mg} \mathrm{mL}^{-1}\right)$ was prepared by suspending this treated quartz DQ12 in HBSS. The solution was sonicated for $5 \mathrm{~min}$ in a water bath and then diluted into the culture dishes to obtain the indicated final concentrations.

\section{Cell Line and Cell Culture}

The human lung adenocarcinoma Type-II alveolar epithelial cells A549 were obtained from the DSMZ (Deutsche Sammlung von Mikroorganismen und Zellkulturen GmbH, Braunschweig, Germany). The cells derived from a 58-year-old male Caucasian with alveolar cell carcinoma [Lieber et al., 1976; Giard et al., 1997] retain many of the characteristics of normal Type-II cells and have been used extensively to assess Type-II cell function [Lechner et al., 1983]. Adherent cells were cultured in plastic flasks in DMEM supplemented with 10\% FBS, 1\% HEPES-Buffer (1 M), $1 \%$ gentamycine in a humidified incubator at $37^{\circ} \mathrm{C}$ with $5 \mathrm{vol} \%$ $\mathrm{CO}_{2}$. A549 cells were harvested with $0.15 \%$ trypsin and $0.08 \%$ EDTA. 


\section{Cell Treatment}

For the experiments, cells were trypsinised at confluency, seeded into 12-well tissue culture plates (Greiner) for the viability assay and the comet assay, or in chambers of QuadriPERM-dishes (Falcon, Heidelberg, Germany) for the CB-MNvit test, and grown until confluency. The cells were rinsed two times with phosphate buffered saline (PBS) and then treated with the toner powder for $24 \mathrm{hr}$. As positive controls, cells were treated with $\mathrm{B}[\mathrm{a}] \mathrm{P}\left(200 \mu \mathrm{mol} \mathrm{L}{ }^{-1}\right)$ and ethyl methanesulfonate (EMS, $2.8 \mathrm{mmol} \mathrm{L}^{-1}$ ) for $24 \mathrm{hr}$. Both the culture medium and the sterile DMSO were used as solvent controls. The positive controls and solvent controls were included concurrently in each experiment. For a further positive control, the cells were treated with suspensions of DQ12 (100 $\mu \mathrm{g} \mathrm{cm}^{-2}$ ). This treatment was carried out in FBS (fetal bovine serum)free medium for $4 \mathrm{hr}$ (comet assay), due to interactions between the quartz particles and serum proteins. These interactions may lead to masking of the toxic effects of the positive particle control. According to our own observations, however, this effect does not occur when exposure is extended to $48 \mathrm{hr}$ (CB-MNvit assay).

\section{Erythrosin B Vital Exclusion Assay}

A549 cells (state of confluence: max. 70\%) were treated for $24 \mathrm{hr}$ with different concentrations of toner powder suspensions and DMSO extracts $\left(80,100,133,200\right.$, and $\left.400 \mu \mathrm{g} \mathrm{cm}^{-2}\right)$. Untreated controls were included in all treatment regimens. Cell viability was evaluated immediately after exposure. Treated cells and solvent control were washed extensively with PBS buffer (PAA, Pasching, Germany) to remove toner particles from each well, harvested by trypsin treatment, and cell counting was performed following erythrosin B staining $\left(1 \mathrm{mg} \mathrm{mL}^{-1}\right.$ in PBS) using a light microscope. In this assay, the membranes of dead cells are permeable to the dye, whereas living cells remain unstained. Additionally, erythrosin B permeates into cells that have sustained critical damage to their plasma membranes. Cell viability is expressed as the percentage of surviving cells compared to the total number of cells. A sample is considered to be cytotoxic to the A549 cells if the decrease in cell viability is $<50 \%$.

\section{Single-Cell Gel Electrophoresis (SCGE, Comet) Genotoxicity Assay}

The comet assay was carried out according to the protocols of Singh et al. [1988] and Tice et al. [2000] with minor modifications. The cells were washed extensively with PBS buffer (PAA, Pasching, Germany). After trypsination with $1 \mathrm{~mL}$ trypsine (PAA, Pasching, Germany) for 5 min, the cell suspension was centrifuged. The supernatant was removed and the cells were then resuspended in $100 \mu \mathrm{L}$ of $0.5 \mathrm{wt} \%$ low-melting point agarose before being transferred onto fully frosted slides and covered with a coverglass. The slides were prepared with a first layer of 1 wt $\%$ normal melting point agarose and a second layer of $0.7 \mathrm{wt} \%$ normal-melting point agarose. The slides were stored for $15 \mathrm{~min}$ at $4{ }^{\circ} \mathrm{C}$ to allow solidification. Following solidification, the coverglasses were removed and the slides immersed in lysis buffer $(2.5 \mathrm{M} \mathrm{NaCl}, 100 \mathrm{mM}$ EDTA-Titriplex, $0.2 \mathrm{M} \mathrm{NaOH}, 1$ vol\% Triton $\mathrm{X}-100, \mathrm{pH}=10$ ) at $4{ }^{\circ} \mathrm{C}$ and stored for $24 \mathrm{hr}$ at the same temperature. Thereafter, the slides were rinsed with distilled water and placed in a horizontal gel electrophoresis chamber (Pharmacia Biotech, Freiburg, Germany) filled with ice-cold electrophoresis buffer $(0.3 \mathrm{M} \mathrm{NaOH}, 1 \mathrm{mM}$ EDTA-Titriplex, $\mathrm{pH}>13)$ for $20 \mathrm{~min}$ subjecting to unwinding under alkaline conditions to allow DNA supercoils to relax and express DNA single strand breaks and al- kali labile sites. Electrophoresis was conducted at $25 \mathrm{~V}$ and $300 \mathrm{~mA}$ for $25 \mathrm{~min}$, followed by a 10-min neutralization with Tris buffer $(0.4 \mathrm{M}$ Tris, $\mathrm{pH}=7.5$ ) and washing twice in distilled water.

To analyze DNA damage in the comet assay, cells were stained with $60 \mu \mathrm{L}$ of an ethidiumbromide solution $\left(0.1 \mu \mathrm{L} \mathrm{mL}{ }^{-1}\right)$. Only the slides treated with DQ12 were stained with $50 \mu \mathrm{L}$ DAPI $\left(0.2 \mu \mathrm{g} \mathrm{mL}{ }^{-1}\right)$ because of the high self-fluorescence of these particles. The slides were coded and analyzed immediately by two observers using a fluorescence microscope (DMLS, Leica, Germany) at 400-fold magnification. At least 100 randomly chosen cells from each slide were analyzed with an imaging software (Kinetic Imaging, UK). With this imaging software the comet parameter OTM (Olive Tail Moment) and additionally the parameter \% Tail DNA were calculated. The \% Tail-DNA is the percent of DNA as fluorescence in the tail; OTM is the product of the percentage of DNA in the tail (\% tail DNA) and the distance between the means of the head and tail fluorescence distributions. OTM was expressed in arbitrary units.

\section{Cytokinesis Block Micronucleus (CB-MNvit) Test}

The CB-MNvit assay is an in-vitro method that uses cultured human or rodent cells. It provides a comprehensive basis for investigating the chromosome-damaging potential in vitro because both aneugens and clastogens can be detected. The CB-MNvit test was carried out according to the guideline of an OECD draft [2007] and the protocol of Fenech [2000]. The cell suspensions, adjusted to a cell density of 100,000 cells per culture $(5 \mathrm{~mL})$, were spread onto microscope slides that were kept in chambers of QuadriPERM-dishes, so that each single chamber was a separate culture. After $24 \mathrm{hr}$-treatment, the cells were washed extensively with PBS buffer to remove dust particles from each slide. Cells were cultured for further $24 \mathrm{hr}$ in the presence of cytochalasin B (final concentration $3 \mu \mathrm{g} \mathrm{mL}^{-1}$ ) to block cell division. At the end of the incubation period, cells were washed with PBS twice and treated with $5 \mathrm{~mL}$ trisodium-citrate solution $(1.5 \mathrm{wt} \%)$ at $37^{\circ} \mathrm{C}$ for $3-5 \mathrm{~min}$. After removing the trisodium-citrate solution, cells were fixed two times with $5 \mathrm{~mL}$ of a fixation solution containing $150 \mathrm{~mL}$ ethanol, $50 \mathrm{~mL}$ acetic acid, and 2.5 $\mathrm{mL}$ of $37 \mathrm{vol} \%$ formaldehyde. Three independent experiments were performed for each toner powder as well as for the quartz DQ12 particles.

\section{Microscopic Evaluation and Micronuclei (MN) Scoring}

After fixation, the cells were stained with a solution of DAPI (0.2 $\mu \mathrm{g}$ $\mathrm{mL}^{-1}$ ). About $50 \mu \mathrm{L}$ of this solution are placed on the glass slide and covered with a coverslip. The preparations were evaluated using a fluorescence microscope (DML, Leica, Germany), with the filter set to 365-nm excitation and 420-nm emission wave length (specific for DAPI). Analysis was performed at 400-fold magnification by one observer. All slides were coded before scoring. The binucleated cells (BNC) were selected according to criteria described by Umegaki and Fenech [2000] and Fenech [2007]. Apoptotic and necrotic cells were included in the total cell number; however micronuclei were not scored in these cells. For each sample, the number of micronuclei (MNBNC) in at least 1,000 BNC was examined and the $\mathrm{MNBNC} / 1,000 \mathrm{BNC}$ ratio was calculated. Round or oval, nonrefractile bodies detached from the nucleus, with smooth outlines and with a diameter not greater than one-third the large diameter of the main nuclei were considered as MN. To rule out cytotoxic effects, the cytochalasin block proliferation index (CBPI) of each sample was evaluated according to Suralles et al. [1995] by assessing 500 cells. The CBPI indicates the number of cell cycles per cell during the period of exposure to cytochalasin $\mathrm{B}$, and is calculated as follows:

$$
\mathrm{CBPI}=\frac{(\text { No. mononucleated cells })+(2 \times \text { No. binucleated cells })+(3 \times \text { No. multinucleated cells })}{\text { total number of cells counted }}
$$



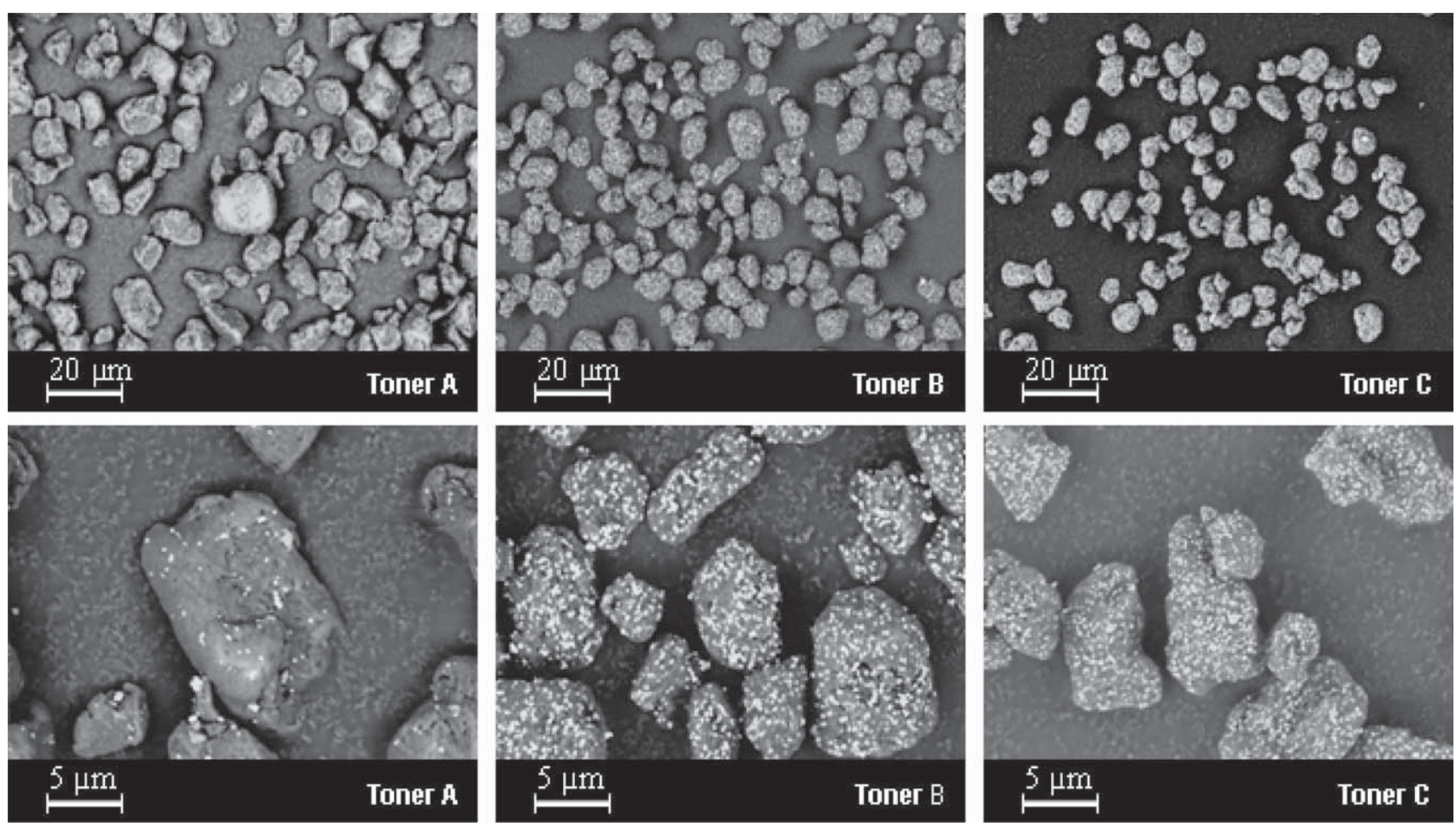

Fig. 1. Back-scattered electron images (BSE) showing size distribution of toner powders A, B, and C. Magnetite particles appear bright, whereas carbon-bearing substrate appears grey. Note that Toners B and C contain more submicrometer-sized magnetite particles than A.
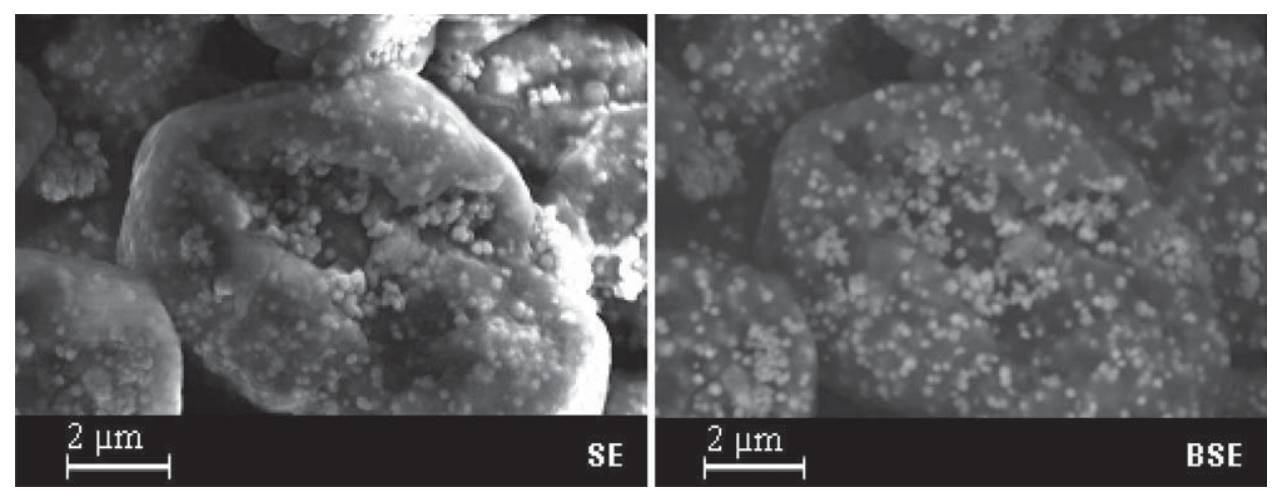

Fig. 2. Secondary electron (SE) and BSE image of Toner B showing rounded magnetite particles (30-200 nm) on carbon-bearing toner particle.

\section{Statistical Analysis}

All data presented are given as mean \pm standard deviation (SD) of three independent experiments. Data shown for the comet assay are mean OTM \pm SD. One-way analysis of variance (ANOVA, SPSS Statistics 17.0, Microsoft) was applied to examine whether the OTM or \% Tail DNA after in-vitro exposure was statistically significantly affected by treatments of cultures with the toner samples. A post-hoc Tukey's test was then used to examine which treated cultures were statistically significantly different from the results of the concurrent untreated control culture. A difference was considered significant at $P$ $<0.05$. Data shown for the micronucleus assay are mean MNBNC/ $1000 \mathrm{BNC} \pm \mathrm{SD}$. The $\chi^{2}$-test was used for comparison of treated cultures with the untreated solvent controls in each set of experiments.

\section{RESULTS}

\section{Particle Size, Morphology, and Composition}

Toner powders consist of carbon-bearing, rounded to slightly elongated particles with typical diameters of 2-12 $\mu \mathrm{m}$ (Fig. 1). The particle surface is slightly rough and is covered by rounded submicrometer-sized particles with a diameter of 30-200 nm (Fig. 2). The EDX spectra document that these nanoparticles are Fe-rich; consistent with the bright appearance of these particles in back-scattered electron (BSE) images (Figs. 1 and 2). The EDX spectra further show that the Fe-rich particles contain consider- 
TABLE I. Concentrations (in $\mathrm{mg} \mathrm{kg}^{-1}$ ) of Selected Elements in the Toner Powders A, B, and C as well as in Their DMSO Extracts

\begin{tabular}{|c|c|c|c|c|c|c|c|c|c|}
\hline Toner type & Material analyzed & $\mathrm{Si}$ & $\mathrm{Fe}$ & $\mathrm{Ni}$ & $\mathrm{Zn}$ & As & $\mathrm{Cd}$ & $\mathrm{Sb}$ & $\mathrm{Pb}$ \\
\hline \multirow[t]{3}{*}{ Toner A } & Total digestion & 76,500 & 30,000 & 5.85 & 35.7 & 31 & $<0.02$ & $<2.5$ & 1.1 \\
\hline & Aqua regia digestion & $<1,000$ & 29,100 & 5.73 & 26.5 & 3.38 & $<0.02$ & $<2.5$ & $<0.25$ \\
\hline & DMSO extract (1:50) & n.a. & 4.6 & 0.004 & $<0.03$ & $<0.005$ & n.a. & n.a. & 0.003 \\
\hline \multirow[t]{3}{*}{ Toner B } & Total digestion & 62,100 & 230,000 & 17.5 & 31.2 & 24 & $<0.02$ & $<2.5$ & 0.8 \\
\hline & Aqua regia digestion & $<1,000$ & 205,000 & 15.6 & 30.7 & 2.54 & $<0.02$ & $<2.5$ & 0.54 \\
\hline & DMSO extract $(1: 50)$ & n.a. & 2.91 & 0.004 & $<0.03$ & $<0.005$ & n.a. & n.a. & 0.004 \\
\hline \multirow[t]{3}{*}{ Toner $\mathrm{C}$} & Total digestion & 57,400 & 280,000 & 23.5 & 72.6 & 22.1 & $<0.02$ & $<2.5$ & 1 \\
\hline & Aqua regia digestion & $<1,000$ & 277,000 & 21.5 & 35.5 & 2.24 & $<0.02$ & $<2.5$ & 0.7 \\
\hline & DMSO extract (1:50) & n.a. & 4.84 & 0.005 & $<0.03$ & $<0.005$ & n.a. & n.a. & 0.004 \\
\hline
\end{tabular}

Notes: n.a. $=$ not analyzed. $\mathrm{SiO}_{2}$ is not soluble in aqua regia.

able amounts of oxygen. The XRD patterns (Fig. 3) reveal the presence of magnetite $\left(\mathrm{Fe}_{3} \mathrm{O}_{4}\right)$ in all three toner powders, demonstrating that the observed $\mathrm{Fe}$-rich submicrometer-sized particles are magnetite. In addition to the magnetite peaks, the XRD patterns show a pronounced broad hump in the background between $\sim 10$ and $25^{\circ} 2 \theta$, which results from the diffuse scattering of X-rays due to the presence of an amorphous phase, which must be the carbonaceous material. This hump in the XRD pattern is especially pronounced for toner Powder A, which, however, exhibits much smaller peaks of magnetite (Fig. 3). The XRD patterns also indicate that small amounts of rutile (tetragonal $\mathrm{TiO}_{2}$ polymorph), cristobalite (tetragonal $\mathrm{SiO}_{2}$ polymorph), and possibly perovskite $\left(\mathrm{CaTiO}_{3}\right)$ might be present in the toner; SEM-EDX spectra of toner particles reveal a small titanium (Ti) peak for toner B and small silicon $(\mathrm{Si})$ peaks for Toners $\mathrm{B}$ and $\mathrm{C}$.

In the toner-powder suspension samples (see Materials and Methods) the carbon-bearing particles still exhibit the same size and remain covered by magnetite particles. As a result of sonication for $20 \mathrm{~min}$, however, some magnetite particles have been separated from their carbonaceous substrate, and frequently form agglomerates or have reaccumulated in surface depressions. These features were not observed in toner-powder samples which were not sonicated prior to SEM investigation.

\section{Chemical Composition of the Toner Powders}

Toner Powders $\mathrm{B}$ and $\mathrm{C}$ show bulk $\mathrm{Fe}$ and nickel (Ni) concentrations that are eight to nine times, respectively three to four times higher than those in toner A (Table I; total digestion). These data are consistent with the higher abundance of magnetite observed in the SEM images (Fig. 2) and XRD patterns (Fig. 3) of toner Powders B and $\mathrm{C}$.

As opposed to total digestion, only the more soluble compounds are dissolved during aqua regia digestion. The data show that the concentration of the more soluble fraction of arsenic (As) is $\sim 10$ times lower than in the bulk toner. Silicon is not detected after aqua regia digestion,

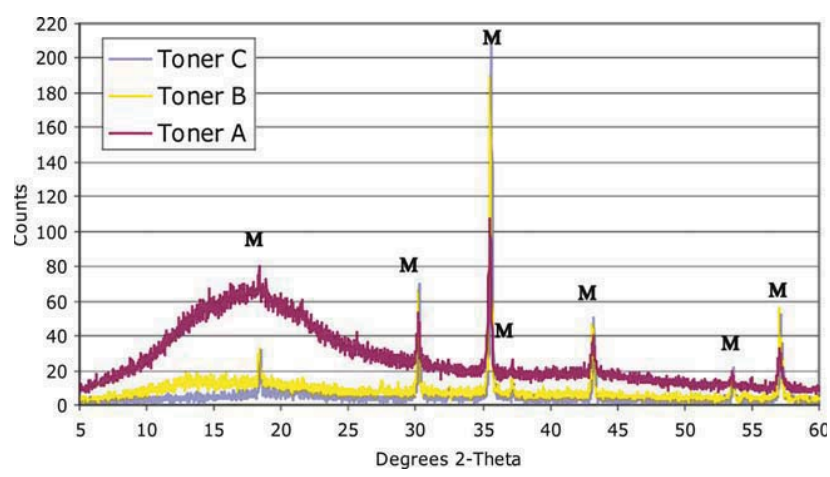

Fig. 3. XRD pattern (spectra) of toner Powders A, B, and $\mathbf{C}$ showing a broad peak of amorphous $\mathrm{C}$-compound and high characteristic peaks of magnetite $(\mathrm{M})$. [Color figure can be viewed in the online issue, which is available at wileyonlinelibrary.com.]

With regard to the other elements analyzed, the two different digestion methods yield concentration differences that are much less pronounced.

To determine whether or not elements had been released from the toner powders to the DMSO extracts, the extracts were also analyzed chemically with the same procedures (see Materials and Methods). The data reveal the presence of $\mathrm{Fe}, \mathrm{Ni}$, and $\mathrm{Pb}$, albeit in very small concentrations in the DMSO extracts (Table I). Only Fe is present on a ppm level. The other elements sought could not be detected in the extracts with the chosen analytical methods.

The three toner powders contain low amounts of PAH (Table II): with the exception of naphthalene, acenaphthylene, and phenanthrene, the concentrations of PAH are below $100 \mu \mathrm{g} \mathrm{kg}^{-1}$, i.e., $<100 \mathrm{ppb}$. The sum of $32 \mathrm{PAH}$ in the toner powders ranged from 405 to $2,623 \mathrm{ppm}$. Toner Powders A and B contain much higher amounts (1-2 orders of magnitude) of most PAHs than toner Powder C.

\section{Cell Viability}

The cell viability of A549 cells treated with toner powder suspensions and with DMSO extracts, as assessed by the erythrosin B vital exclusion assay after $24 \mathrm{hr}$, is 
TABLE II. PAH Concentrations $\left(\mu \mathrm{g} \mathrm{kg}^{-1}\right.$ ) in Toner Powders A, $B$, and $\mathrm{C}$

\begin{tabular}{|c|c|c|c|}
\hline PAH & Toner A & Toner B & Toner $\mathrm{C}$ \\
\hline Naphthalene & 325.55 & 577.08 & 376.91 \\
\hline Acenaphthylene & 39.30 & 117.88 & 1.03 \\
\hline Acenaphthene & 5.55 & 78.36 & 5.57 \\
\hline Fluorene & 2.58 & 35.78 & 4.97 \\
\hline Phenanthrene & 76.93 & 1657.37 & 9.25 \\
\hline Anthracene & 1.04 & 42.69 & 0.56 \\
\hline Fluoranthene & 14.22 & 8.97 & 1.19 \\
\hline Pyrene & 54.39 & 47.26 & 1.73 \\
\hline Benzo $[c]$ fluorene & 0.09 & 0.06 & $<0.05$ \\
\hline Benzo $[b]$ naphtho $[2,1-d]$ thiophene & 0.06 & 0.13 & 0.10 \\
\hline Benzo[ghi]fluoranthene & 4.41 & 3.50 & 0.10 \\
\hline Benzo $[c]$ phenanthrene & 0.21 & 0.16 & 0.05 \\
\hline Benzo $[a]$ anthracene & 0.33 & 0.56 & 0.18 \\
\hline Cyclopenta $[c d]$ pyrene & $<0.07$ & 25.14 & 1.84 \\
\hline Triphenylene & 0.22 & 0.52 & 0.18 \\
\hline Chrysene & 0.62 & 0.38 & 0.19 \\
\hline 5-Methylchrysene & $<0.03$ & $<0.03$ & $<0.03$ \\
\hline Benzo $[b]$ fluoranthene & 0.36 & 0.22 & 0.15 \\
\hline Benzo $[k]$ fluoranthene & 0.17 & 0.07 & 0.05 \\
\hline Benzo[j]fluoranthene & 0.16 & 0.07 & 0.05 \\
\hline Benzo $[b+j+k]$ fluoranthene & 0.69 & 0.36 & 0.25 \\
\hline Benzo $[e]$ pyrene & 1.24 & 0.91 & 0.13 \\
\hline Benzo $[a]$ pyrene & 0.76 & 0.66 & $<0.08$ \\
\hline Perylene & 0.14 & 0.09 & $<0.05$ \\
\hline Indeno[1,2,3-cd]pyrene & 0.68 & 0.86 & $<0.06$ \\
\hline Dibenzo $[a, h]$ anthracene & $<0.02$ & $<0.02$ & $<0.02$ \\
\hline Benzo[ghi]perylene & 4.88 & 8.92 & 0.09 \\
\hline Anthanthrene & 0.80 & 1.21 & $<0.04$ \\
\hline Dibenzo $[a, l]$ pyrene & $<0.04$ & $<0.04$ & $<0.04$ \\
\hline Dibenzo[a,e]pyrene & $<0.04$ & $<0.04$ & $<0.04$ \\
\hline Dibenzo[a,i]pyrene & $<0.04$ & $<0.04$ & $<0.04$ \\
\hline Dibenzo $[a, h]$ pyrene & $<0.04$ & $<0.04$ & $<0.04$ \\
\hline Coronene & 3.81 & 13.75 & $<0.04$ \\
\hline Sum of $32 \mathrm{PAH}$ & 539.47 & 2623.17 & 405.10 \\
\hline
\end{tabular}

shown in Figures $4 \mathrm{~A}$ and $4 \mathrm{~B}$. None of the toner samples was able to reduce cell viability by $50 \%$. These results reveal no impact of toner powder suspensions and DMSO extracts (i.e., devoid of particles) on cell viability. In conclusion, neither toner powder suspensions nor DMSO extracts were cytotoxic up to concentrations of $400 \mu \mathrm{g}$ $\mathrm{cm}^{-2}$ to A549 cells after 24-hr exposure.

\section{Induction of DNA Migration}

After 24-hr exposure of A549 cells, all the toner powder suspensions induced statistically significant increases in DNA migration in a concentration-dependent manner (1.5-4 times higher than the solvent control; $P<0.05$, Tukey's test), represented in terms of OTM (Fig. 5A). These effects were lower for all toner samples than for the positive controls quartz DQ 12 (4-hr exposure; $100 \mu \mathrm{g}$ $\mathrm{cm}^{-2}$; OTM: $\left.1.90 \pm 0.05\right)$ and $\mathrm{B}[\mathrm{a}] \mathrm{P}\left(200 \mu \mathrm{mol} \mathrm{L}{ }^{-1}\right.$; OTM: $1.66 \pm 0.07)$. The suspension of toner Powder $\mathrm{C}$ was less active than either toner Powders A or B. Similar results were obtained for the DMSO extracts (Fig. 5B; $P$
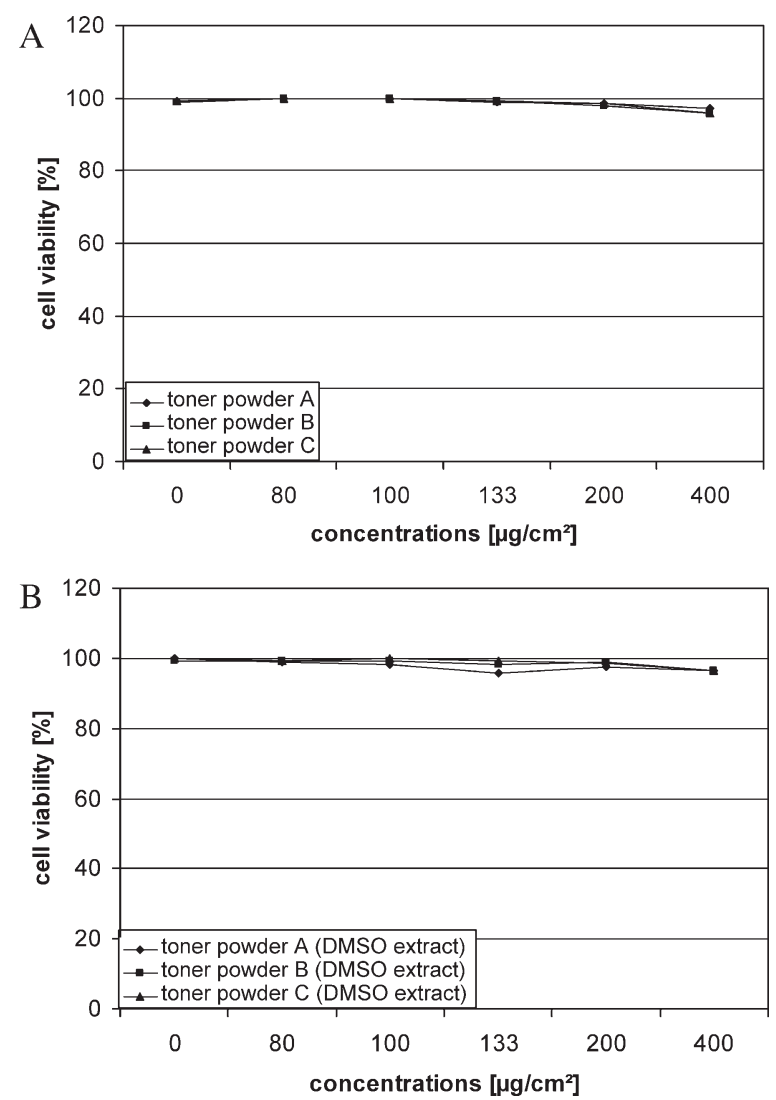

Fig. 4. Cell viability in human lung cells (A549) monitored by the erythrosin B vital exclusion assay following 24-hr exposure to toner suspensions (A) or DMSO extracts (B). Positive controls: quartz DQ12 (100 $\mu \mathrm{g} \mathrm{cm}^{-2}$; cell viability $\left.[\%]=76.66 \pm 1.53\right)$ and $\mathrm{B}[\mathrm{a}] \mathrm{P}\left(200 \mu \mathrm{mol} \mathrm{L}{ }^{-1}\right.$; cell viability $[\%]=81.33 \pm 2.08)$. The percentage of cell viability is shown in relation to the solvent controls $\left(0 \mu \mathrm{g} \mathrm{cm} \mathrm{cm}^{-2}=100 \%\right)$. Each symbol represents the mean of three independent experiments.

$<0.05$, Tukey's test): the extract of toner Powder B caused the highest level of DNA migration, and, at a concentration of $400 \mu \mathrm{g} \mathrm{cm} \mathrm{cm}^{-2}$, was slightly less genotoxic than the positive controls. Since OTM and \% Tail DNA are the most commonly used parameters in comet analysis, we further evaluated the extent of DNA migration in terms of $\%$ Tail DNA. These results are shown in Figures $6 \mathrm{~A}$ and $6 \mathrm{~B}$.

DNA migration elicited by the toner samples was similar in trend for this parameter to that observed for OTM, although statistically significant concentration-dependent DNA migration was only observed for Toner B. The \% Tail DNA was significantly increased for suspensions of Toner A and C, as well as for the DMSO extract of Toner A at concentrations of $400 \mu \mathrm{g} \mathrm{cm}^{-2}$ (Figs. 6A and 6B; $P$ $<0.05$, Tukey's test). DMSO extract of Toner C showed no statistically significant effect compared to the corresponding control $(P>0.05$, Tukey's test).

In conclusion, the extent of DNA damage varied depending on toner samples and preparations. Toner B 

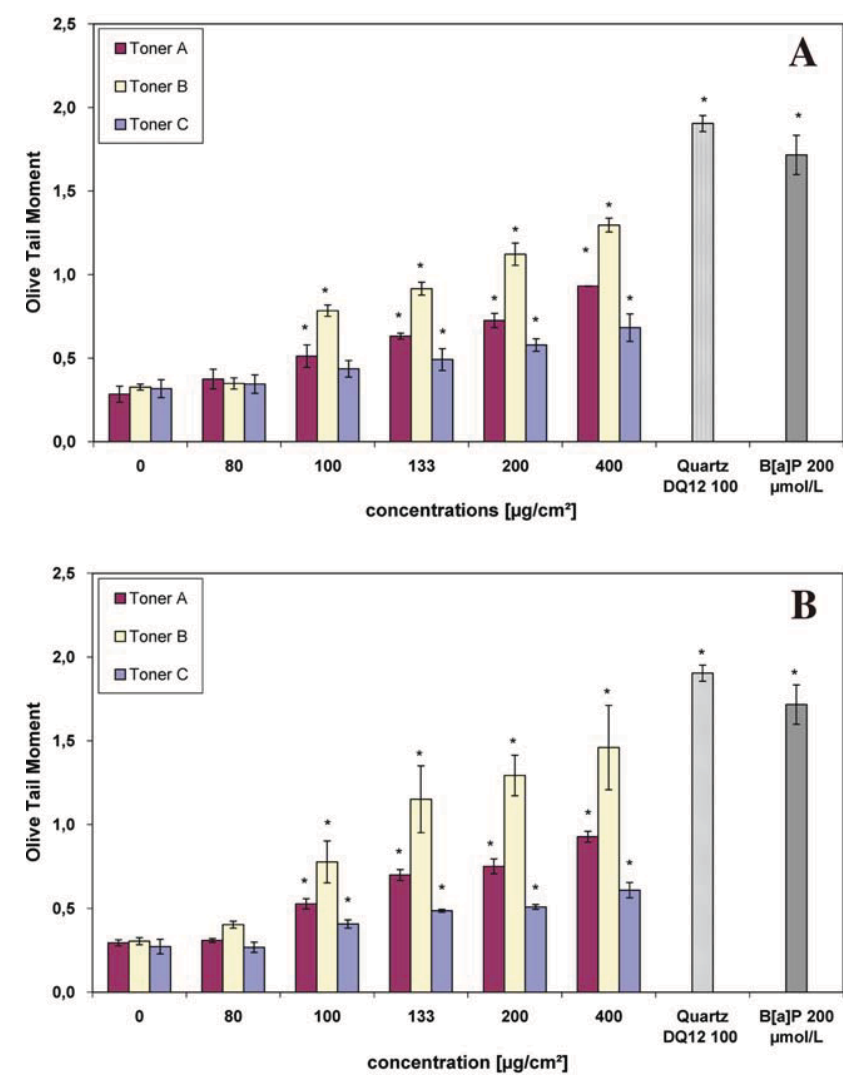

Fig. 5. DNA damage as measured by the comet assay and expressed as Olive Tail Moment (arbitrary units) in cultured human lung cells (A549) after 24-hr exposure to various concentrations of toner powder suspensions (A) and their DMSO extracts (B). Positive controls: quartz DQ12 $\left(100 \mu \mathrm{g} \mathrm{cm}^{-2}\right.$, 4-hr treatment) and $\mathrm{B}[\mathrm{a}] \mathrm{P}\left(200 \mu \mathrm{mol} \mathrm{L}{ }^{-1}\right)$. Data are mean $\pm \mathrm{SD}$ of three independent experiments. *These treatments resulted in a statistically significant effect in comparison to solvent controls $\left(0 \mu \mathrm{g} \mathrm{cm}^{-2}\right)$ in one-way ANOVA followed by Tukey's test-post hoc comparisons of means, at the level of significance of $P<0.05$. [Color figure can be viewed in the online issue, which is available at wileyonlinelibrary.com.]

showed the highest induction of DNA damage, followed by Toner $\mathrm{A}$. Toner $\mathrm{C}$ was the least genotoxic.

\section{Induction of Micronuclei}

Figures 7 and 8 shows the level of induced micronuclei in A549 cells by the toner-powder suspensions and their DMSO extracts after $24 \mathrm{hr}$ of exposure to concentrations of $80,100,133,200$, and $400 \mu \mathrm{g} \mathrm{cm}^{-2}$. MN formation in $\mathrm{BNC}$ resulting from the treatment of the cells with the solvent controls (culture medium, DMSO) was 4-8 MNBNC/1,000 binucleated cells (BNC). The positive controls showed a higher incidence of micronuclei (16-35 MNBNC/1,000 BNC), whereby the effects were in the

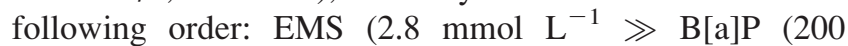
$\left.\mu \mathrm{mol} \mathrm{L} \mathrm{L}^{-1}\right) \gg \operatorname{DQ12}$ (48-hr exposure;100 $\mu \mathrm{g} \mathrm{cm} \mathrm{cm}^{-2}$ ). DMSO extract of toner Powder $\mathrm{C}$ did not have any significant effect on $\mathrm{MN}$ formation at all concentrations up to
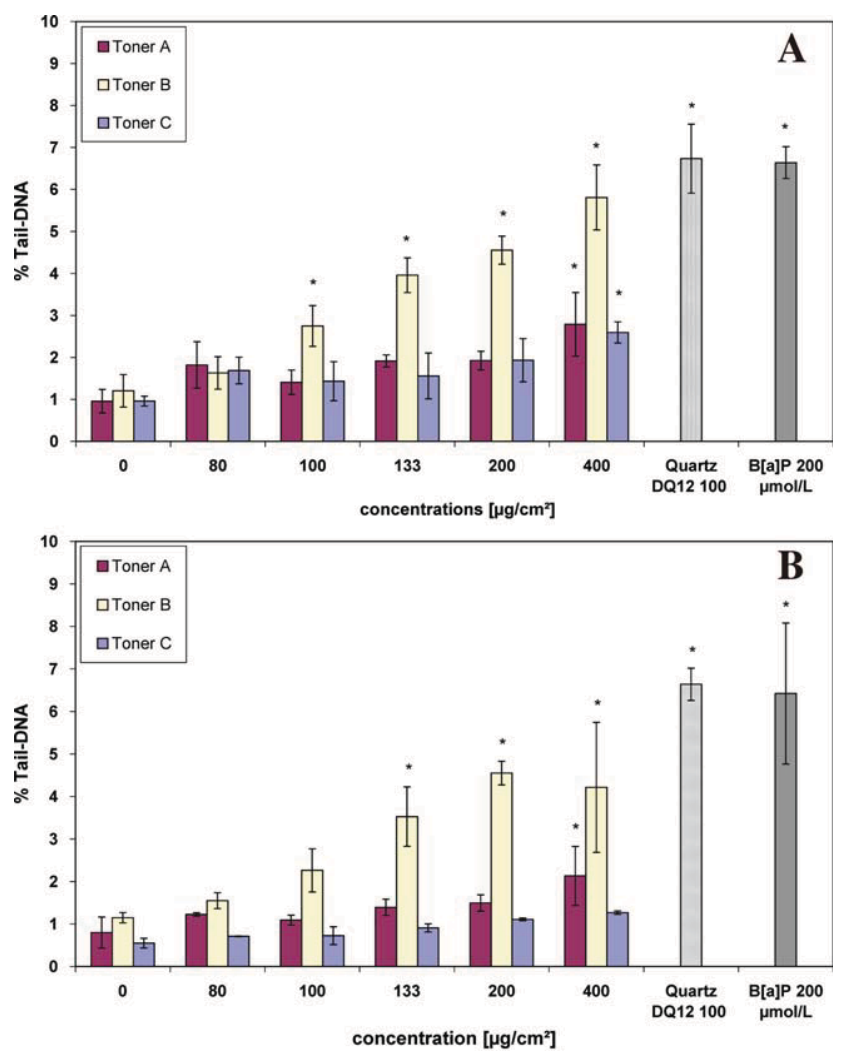

Fig. 6. DNA damage as measured by the comet assay and expressed as $\%$ Tail-DNA in cultured human lung cells (A549) after 24-hr exposure to various concentrations of toner powder suspensions (A) and their DMSO extracts (B). Positive controls: quartz DQ12 (100 $\mu \mathrm{g} \mathrm{cm}^{-2}$, 4-hr treatment) and $\mathrm{B}[\mathrm{a}] \mathrm{P}\left(200 \mu \mathrm{mol} \mathrm{L}^{-1}\right)$. Data are mean $\pm \mathrm{SD}$ of three independent experiments. *These treatments resulted in a statistically significant effect in comparison to solvent controls $\left(0 \mu \mathrm{g} \mathrm{cm}^{-2}\right)$ in one-way ANOVA followed by Tukey's test-post hoc comparisons of means, at the level of significance of $P<0.05$. [Color figure can be viewed in the online issue, which is available at wileyonlinelibrary.com.]

$400 \mu \mathrm{g} \mathrm{cm}^{-2}\left(P>0.05, \chi^{2}\right.$ test $)$. A clear concentrationdependency was observed for both suspension and DMSO extract of toner A $\left(P<0.05, \chi^{2}\right.$ test $)$. Suspension and DMSO extract of Toner-B induced MN formation only at concentrations of 200 and $400 \mu \mathrm{g} \mathrm{cm}{ }^{-2}\left(P<0.05, \chi^{2}\right.$ test). In contrast to the DMSO extract, the suspension of toner $\mathrm{C}$ increased the number of MNBNC at concentrations of 200 and $400 \mu \mathrm{g} \mathrm{cm}{ }^{-2}\left(P<0.05, \chi^{2}\right.$ test $)$. Cell cycle delays (cytostatic effects) induced by the toner powders were measured by the CB-MNvit test and expressed by the parameter CBPI. CBPI of $<1.5$ indicating a slight inhibition of cell proliferation, was found for the positive control B[a]P (200 $\left.\mu \mathrm{mol} \mathrm{L}{ }^{-1}\right)$, for toner powder suspension $\mathrm{A}\left(200 \mu \mathrm{g} \mathrm{cm}^{-2}\right)$ and for the highest concentration of all other toner samples $\left(400 \mu \mathrm{g} \mathrm{cm}^{-2}\right)$. In conclusion, CBPI was not markedly affected by treatment with concentrations of the toner samples.

In summary, our results show that all toner-powder suspensions, which contain $\mathrm{Si}, \mathrm{Fe}$, other metals or metalloids 

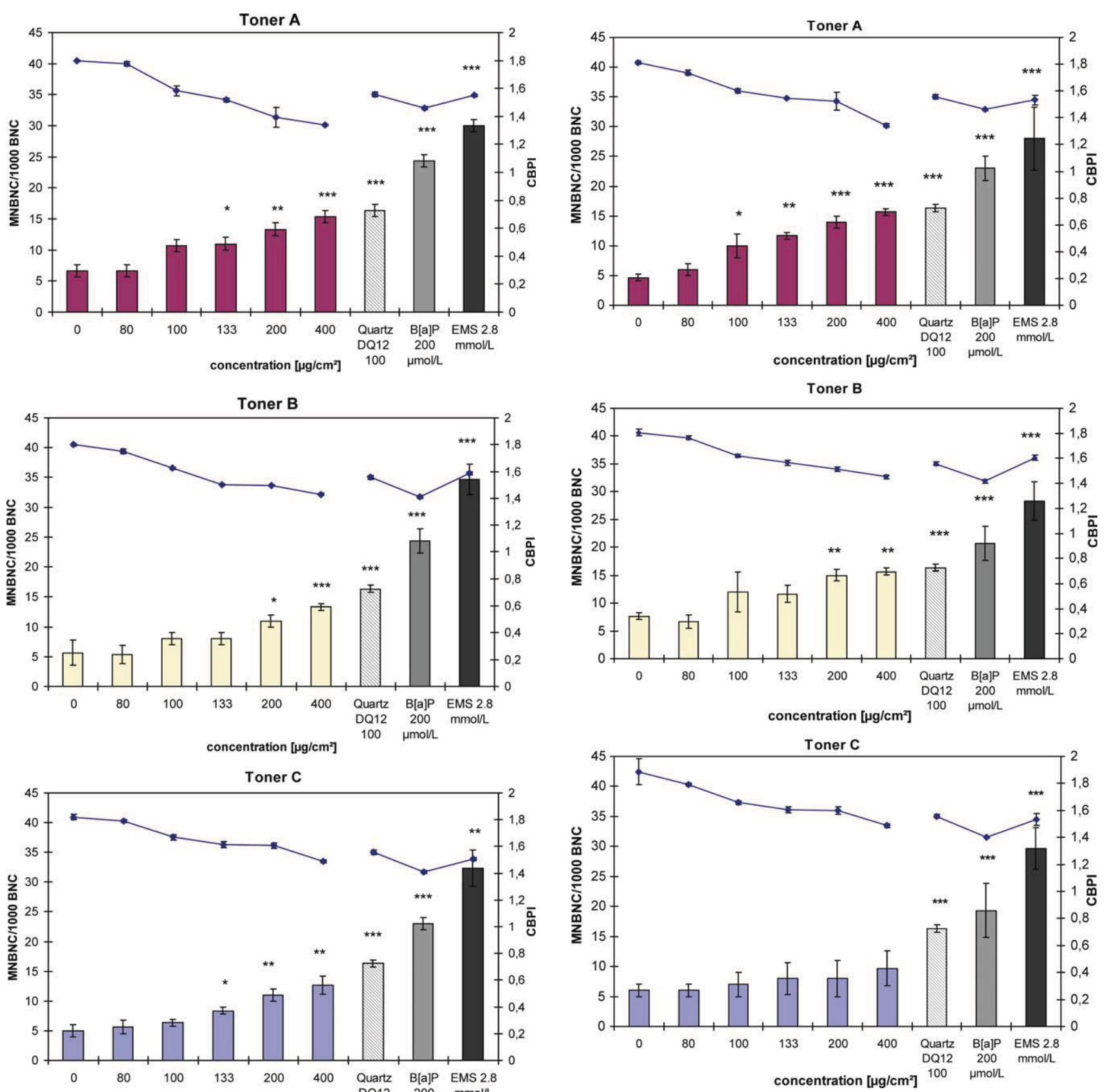

Fig. 8. Frequency of micronucleated binucleate cells (MNBNCs) per 1,000 binucleate cells (BNCs) and cytokinesis block proliferation index (CBPI) in cultured human lung cells (A549) after 24-hr exposure to various concentrations of toner powder DMSO extracts A, B, and C. Positive controls: quartz DQ12 (100 $\mu \mathrm{g} \mathrm{cm}^{-2}, 48$-hr treatment), B[a]P (200 $\left.\mu \mathrm{mol} \mathrm{L}{ }^{-1}\right)$, and EMS $\left(2.8 \mathrm{mmol} \mathrm{L}^{-1}\right)$. Data represent mean MNBNC/ $1,000 \mathrm{BNC} \pm \mathrm{SD}$ from three independent experiments. Asterisks show those data points that were statistically significantly higher than the results obtained from the untreated control cultures $\left(0 \mu \mathrm{g} \mathrm{cm}^{-2}\right)$ in the $\chi^{2}$ test; $* P<0.05 ; * * P<0.01 ; * * * P<0.001$. [Color figure can be viewed in the online issue, which is available at wileyonlinelibrary.com.] obtained from the untreated control cultures $\left(0 \mu \mathrm{g} \mathrm{cm}^{-2}\right)$ in the $\chi^{2}$ test; $* P<0.05 ; * * P<0.01 ; * * * P<0.001$. [Color figure can be viewed in the online issue, which is available at wileyonlinelibrary.com.] 
TABLE III. Summary of Observed Toxicological Effects of Toner-Powder Suspensions and Their DMSO Extracts at Concentrations of 80, 100, 133, 200, and $400 \mu \mathrm{g} \mathrm{cm}^{-2}$, Including Reduction of Cell Viability (Erythrosin B Vital Exclusion Assay), DNA Damage (Comet Assay; Parameter OTM in Arbitrary Units) and Induction of MNBNC (CB-MNvit)

\begin{tabular}{|c|c|c|c|c|c|c|}
\hline \multirow{2}{*}{$\begin{array}{l}\text { Experiment } \\
\text { Endpoint }\end{array}$} & \multicolumn{3}{|c|}{ Toner-powder suspensions } & \multicolumn{3}{|c|}{ Toner-powder extracts (DMSO) } \\
\hline & $\begin{array}{l}\text { Reduction of } \\
\text { cell viablity }\end{array}$ & DNA damage & $\begin{array}{c}\text { Induction of } \\
\text { MNBNC }\end{array}$ & $\begin{array}{c}\text { Reduction of cell } \\
\text { viablity }\end{array}$ & DNA damage & $\begin{array}{r}\text { Induction of } \\
\mathrm{MNBNC}\end{array}$ \\
\hline Toner A & - & ++ & +++ & - & ++ & +++ \\
\hline Toner B & - & +++ & ++ & - & +++ & ++ \\
\hline Toner C & - & + & ++ & - & + & - \\
\hline
\end{tabular}

,+++ , and +++ are used to depict weak, moderate, and strong concentration-dependent effects, respectively; - is used to depict the absence of an effect.

and PAHs, and the toner-powder DMSO extracts A and $\mathrm{B}$, which contain no particles $>220 \mathrm{~nm}$, and which are poor in metals and metalloids, can cause DNA damage and induction of micronuclei in human lung epithelial cells in vitro. Only DMSO extract of toner Powder C was seen to be negligibly toxic in both genotoxicity assays. The outcome of the cell viability assay shows toner-powder suspensions, respectively DMSO extracts to be noncytotoxic. A comparative qualitative summary of the results of the toxicological effects induced by the investigated toner samples, including cytotoxicity (erythrosin B vital exclusion assay) and genotoxicity (comet, CB-MNvit) is given in Table III.

\section{DISCUSSION}

For some years now, exposure to toner powders or to their emissions released into indoor air during laser printer and photocopier operation and maintenance has been discussed as a possible cause of health complaints, especially regarding effects on the respiratory tract and the immunological and nervous systems. A growing number of people have reported to react sensitively when exposed to toner powder or toner emissions [Stelting, 2006]. In Germany, a registered society has been formed, which to date has registered more than 2,000 suspicious cases of disorders possibly related to toner-powder or laser printer-emission exposure [Stelting, 2006].

As discussed below, data on the toxicity, especially the cytotoxicity and genotoxicity of toner powders are inconsistent. Therefore, from a toxicological point of view, an investigation of size, shape, and chemical composition, as well as of the cell toxic effects caused by toner powders is essential.

There are numerous in-vivo studies with animals, human-exposure studies, investigations with human effect markers (biomonitoring), as well as epidemiological and occupational studies addressing the toxicity of toner powders. However, the results suggest that neither acute nor chronic oral, dermal, or inhalative toxicity can be expected from toner powders, even at high concentrations [Gminski and Mersch-Sundermann, 2006]. For example, extensive chronic inhalation studies in rodents did not reveal toxic effects from exposure to toner powders [Möller et al., 2004; Slesinski and Turnbull, 2008]. In contrast, however, a study by Pott and Roller [2005] revealed that chronic inhalation exposure of rodents to toner powders (concentration: $>10 \mathrm{mg}$ of toner powder per $\mathrm{m}^{3}$ air) led to an increase in the weight of the lung (due to fibrosis), cell proliferation, and reduced pulmonary clearance, but it did not enhance carcinoma incidence. Furthermore, several in-vitro studies examined various toner powders with regard to their cytotoxic, genotoxic, and mutagenic potential in bacteria and cell models. The toxicological endpoints investigated included: DNA damage and mutation in Salmonella/microsome assay [Löfroth et al., 1980; Lin, 1999; Möller et al., 2004], induction of sister chromatid exchange (SCE) and cell transformation [Lin, 1999]. Moreover, studies on cytotoxicity [Furukawa et al., 2002; Möller et al., 2004] and release of inflammatory and reactive oxygen species (ROS) [Nies et al., 2000; Furukawa et al., 2002; Möller et al., 2004] have been performed.

None of the results of these in-vitro studies indicate that toner powders or their extracts are either cytotoxic or genotoxic, or that ROS are produced. At very high concentrations, a weak release of Tumor Necrosis Factoralpha $(\mathrm{TNF}-\alpha)$ and the cytoplasmatic enzyme LDH has been noted in alveolar macrophages from rats and guinea pigs, indicating some inflammatory and membrane damaging effects of toner powder [Möller et al., 2004].

Evidence for the mutagenicity of commercially available toner powder as DMSO and acetone extracts was found in two earlier studies employing the Salmonella assay with established S. typhimurium strains with and without S9-mix [Löfroth et al, 1980; Rosenkranz et al., 1980]. These findings were attributed to the content of the $\mathrm{PAH}$ nitropyrene as a contaminant in the CB. In contrast, Lin [1999] and Möller et al. [2004] found no mutagenicity in the Salmonella assay for toner powders using acetone or DMSO extracts, even at concentrations of up to 10 mg per Petri dish.

Cytogenetic and haematologic biomonitoring studies undertaken on photocopy machine operators exposed to 
toner emissions during their work found genotoxic effects in lymphocytes and buccal mucosa cells [Goud et al., 2001, 2004; Gadhia et al., 2005].

All these findings must be interpreted with caution, because only a few toner powders were examined, mostly in an unsystematic fashion, and the results are inconsistent.

To examine a possible toxicological hazard associated with this type of fine particle, we characterized three selected individual toner particles in terms of their size, shape, surface structure, and elemental composition by using various mineralogical and geochemical techniques (XRD; SEM combined with EDX spectrometry). The bulk chemical composition of the toner powders was determined by AAS, photometry and GC-MS. To assess the cytotoxic and genotoxic potential of the toner powders we used the erythrosin B vital exclusion assay, the comet and the CB-MNvit assays. The erythrosin B assay detects cells with functionally undamaged membranes to be viable even if they have lost the ability to proliferate [Krause et al., 1984]. The alkali version of the comet assay is a sensitive method capable of detecting and quantifying various levels of DNA damage, including double and single-strand DNA breaks, which include indirect origins from incomplete excision repair and alkali-labile sites [Singh et al., 1988]. The comet assay endpoints \% TailDNA and OTM are considered to be sensitive and reliable scores for measuring DNA damage [Kumaravel and Jha, 2006]. The CB-MNvit assay is an in-vitro method that measures chromosome damage originating from chromosomal fragments lacking centromeres and/or whole chromosomes that are unable to reach the spindle poles during mitosis [Fenech, 2007]. The occurrence of induced MN reflects the extent of chromosomal changes. We chose 24$\mathrm{hr}$ treatment because we wished to allow the toner particles to gain access to the cells and to interfere with DNA. Considering that the branching of the airways may yield hot spots where relatively high concentrations of particulate matter can be reached, we investigated concentrations from 80 to $400 \mu \mathrm{g} \mathrm{cm}^{-2}$, i.e., the concentrations that can be expected under "worst case conditions." However, even under these conditions no cytotoxicity was found for all tested concentrations of the toner samples.

\section{Size}

Particles smaller than $10 \mu \mathrm{m}$ are considered to be respirable, particles smaller than $2.5 \mu \mathrm{m}$ penetrate into the deeper lungs reaching the alveoli, while particles smaller than $100 \mathrm{~nm}$ (ultrafine particles) are suspected to cross the blood-brain-barrier, entering the blood stream and reaching organs and the brain [Eschbacher et al., 2000; BéruBé et al., 2007]. As described above, the toner particles studied here consisted of rounded particles with diameters of $2-12 \mu \mathrm{m}$, covered by rounded submicrome- ter-sized particles with diameters of 30 to $200 \mathrm{~nm}$. The results of the EDX and XRD analysis imply that the nanoparticles are magnetite. No loose magnetite particles were observed in toner-powder samples that had not been sonicated, whereas after sonication some magnetite particles were separated from the carbonaceous substrate and in many cases formed agglomerates (Fig. 2). Our observations are consistent with a previous toner-powder study in which carbonaceous particles with Fe-bearing nanoparticles attached to the surface were observed [Mersch-Sundermann, 2008]. A recent study by Rödelsperger et al. [2006] documented the existence of Al-Si nanoparticles with a diameter of 10-20 nm in toner-powder suspensions after sonication. However, these findings could not be verified in our study.

The DMSO extracts proved to be genotoxic, but not cytotoxic. Since the DMSO extracts were filtered $(<220$ $\mathrm{nm}$; sterile environment), they only contained particles smaller than $220 \mathrm{~nm}$ as well as the DMSO-soluble components of the toner particles. Because most of the magnetite particles are attached to the larger carbonaceous particles $(2-12 \mu \mathrm{m})$, it is unlikely that they are present in the DMSO extracts.

\section{Chemical Composition}

According to the manufacturers' specification, toner powders are generally a mixture of plastic resin and $\mathrm{CB}$, often with other additives such as magnetite, $\mathrm{SiO}_{2}$ and $\mathrm{TiO}_{2}$, whereby the CB particles are incorporated into a polymer matrix. Significant bioavailability in the smaller airways of the lung is therefore unlikely. However, after sonication (or heating during the printing process), the polymer matrix may be destroyed, making $\mathrm{CB}$ including PAH impurities bioavailable to epithelial cells. PAH bind to cytosolic receptors and may therefore affect cell growth and differentiation [Bayram et al., 1998]. Some PAHs are human mutagens and carcinogens [Bostrom et al., 2002]. Since PAHs occurred in all three toner-powder samples (Table II), we conclude that these compounds are responsible for the genotoxic effects determined by the comet and CB-MNvit assays.

The examined toner powders contain large amounts of magnetite, which serves as a pigment. Preliminary in-vitro experiments with human lung cells exposed to pure magnetite of different particle sizes $(0.5-10 \mu \mathrm{m})$ revealed no cytotoxic effects, but is also able to induce micronuclei in human lung cells [Könczöl et al., in preparation]. This crystalline (Fig. 3) ferrimagnetic phase, however, may incorporate several types of metal impurities, including $\mathrm{V}$, $\mathrm{Cr}, \mathrm{Co}, \mathrm{Ni}$, and $\mathrm{Zn}$ [Deer et al., 1992]. The elemental analysis of the tested toner powders (Table I) documents that $\mathrm{Ni}$ and $\mathrm{Zn}$ are present in the toners, in addition to other metals and As (V, Cr, and Co have not been analyzed). The data in Table I show that $\mathrm{Fe}, \mathrm{Ni}$, and $\mathrm{Zn}$ are 
present in a relatively soluble form (aqua regia digestion), whereas $\mathrm{Pb}$ and the metalloids $\mathrm{Si}$ and $\mathrm{As}$ are mostly present in a more dissolution-resistant form (total digestion), suggesting that they are associated with different materials in the toner powders. We conclude that $\mathrm{Ni}$ and $\mathrm{Zn}$ are associated with magnetite. The data for $\mathrm{Si}$ show that $\mathrm{Si}$ is present mostly as $\mathrm{SiO}_{2}$ particles (not soluble in aqua regia), whereas we suspect that $\mathrm{As}$ and $\mathrm{Pb}$ are associated with the carbonaceous fraction. Several of these elements are suspected of causing toxic effects. For example, $\mathrm{Ni}$ and As are known to be harmful to human health [Seilkop and Oller, 2003]. Nickel can elicit allergic skin reactions in humans who are sensitive to this element. Based on studies of nickel workers and laboratory animals, all $\mathrm{Ni}$ compounds, except for metallic $\mathrm{Ni}$, have been classified as human carcinogens [Ott et al., 1974]. The toxicity of $\mathrm{Ni}$ compounds may be related to enhance ROS production, which plays an important role in carcinogenesis [IARC, 1990]. Another harmful compound present in the toner powders is As. Inhalation is the primary route of exposure to As at the workplace and is known to occur during several industrial processes [Ott et al., 1974; Enterline et al., 1995]. Overall, IARC classified As and inorganic As compounds as "carcinogenic to humans" (Group 1), [Straif et al., 2009].

Crystalline silica is able to induce cytotoxicity, in addition to increased production and release of proinflammatory cytokines, and has been extensively investigated both in vitro and in vivo [Donaldson and Borm, 1998; Fubini, 1998; Hetland et al., 2001; Ovrevik et al., 2004; Rimal et al., 2005; Wang et al., 2007]. The concentrations of bulk Si (Table I) are similar in all the investigated toner powders $(\mathrm{Si}=5.7-7.6 \mathrm{wt} \%)$, but they did not show any cytotoxic effects in human lung cells.

We found significant genotoxicity for toner powder suspensions $\mathrm{A}$ and $\mathrm{B}$, as well as for the filtered DMSO extracts, which contain hardly any metals or metalloids (Table I). Therefore, we conclude that these genotoxic effects are not only linked to the metal or metalloid content of the samples. PAHs, which are known to be mutagenic and carcinogenic to humans, are present in the investigated toner-powders. It is therefore more likely that the PAHs are responsible for the observed genotoxic effects of Toner A and B. Especially the B[a]P content in Toners A and B correlates very well with the concentration-response for MN induction and DNA damage expressed as OTM. Moreover, Toner C, which contains no Carbon Black and consequently fewer PAHs, and, in particular, which has no detectable $\mathrm{B}[\mathrm{a}] \mathrm{P}$ content (Table II), either showed no or at most moderate concentrationdependent genotoxic effects in the bioassays. Furthermore, as seen in the case of Toner-powder $\mathrm{C}$ suspension, the particles themselves or the metal content may be in part responsible for causing a genotoxic effect, because the effect was diminished in the DMSO extracts, which con- tain no particles and no metals or metalloids. In this context, the mechanism of secondary genotoxicity can be mentioned: Particle deposition deep in the lung can lead to generation of ROS followed by chronic inflammation and fibrosis. This imbalance of ROS cannot be compensated by intracellular mechanisms and serves to promote cancer [Rödelsperger and Roller, 2003]. Therefore, these authors concluded that potential health hazards of tonerpowder suspensions cannot be excluded.

In conclusion, this is the first study indicating that the commercially available black toner powders examined are genotoxic in human lung cells in vitro. These effects cannot be linked to one particular substance or mechanism, but to a complex interaction of particles, their metal content and their PAH contaminants. The genotoxicity observed is most likely either caused by the PAH content and partly by the particles themselves, or by the presence of particles and their metal content.

Since technology advances rapidly, the composition of toner powders is subject to constant change, and the size of the toner particles will decrease to achieve higher print quality. Especially the smaller particles should be subjected to further scrutiny, because their physicochemical properties differ on the nanoscale [Hochella et al., 2008] and therefore probably have other toxicological effects. To evaluate the relevance of our in-vitro findings for induction of heritable mutations or for induction of cancer from exposure of humans to toner-powders or to their emissions during laser printing, more detailed studies, especially human biomonitoring studies or studies applying in vivo toxicity tests, are necessary.

\section{ACKNOWLEDGMENTS}

The authors thank Sigrid Hirth-Walther and Isolde Schmidt for their assistance with AAS, photometry, and XRD at the Department of Geosciences, Freiburg, Germany. They also thank Andreas Danilewsky and Christoph Neururer for technical assistance with SEM analysis on the Departments of Geosciences in Freiburg, Germany and Fribourg, Switzerland, respectively. Furthermore, they thank Deborah Lawrie-Blum for language assistance.

\section{REFERENCES}

Armbruster C, Dekan G, Hovorka A. 1996. Granulomatous pneumonitis and mediastinal lymphadenopathy due to photocopier toner dust. Lancet 348:690.

Aufderheide M, Knebel JW, Ritter D. 2003. An improved in-vitro model for testing the pulmonary toxicity of complex mixtures such as cigarette smoke. Exp Toxic Pathol 55:51-57.

Bayram H, Devalia JL, Sapsford RJ. 1998. The effects of diesel exhaust particles on cell function and release of inflammatory mediators from human bronchial epithelial cells in vitro. Am J Respir Cell Mol Biol 18:441-448. 
BéruBé K, Balharry D, Sexton K, Koshy L, Jones T. 2007. Combustionderived nanoparticles, mechanisms of pulmonary toxicity. Clin Exp Pharmacol Physiol 34:1044-1050.

Bostrom CE, Gerde P, Hanberg A, Jernstrom B, Johansson C, Kyrklund K, Törnqvist M, Victorin K, Westerholm R. 2002. Cancer risk assessment, indicators, and guidelines for polycyclic aromatic hydrocarbons in the ambient air. Environ Health Perspect 110:451-488.

Canham ML. 1996. An evaluation of the potential health hazards associated with toner cartridge recycling industry. Appl Occup Environ Hyg 11:1033-1037.

Deer WA, Howie RA, Zussman J. 1992. An Introduction to the RockForming Minerals, 2nd ed . New Jersey:Prentice Hall.

DEV. 2009. German Standard Methods for the Examination of Water, Wastewater, and Sludge. Weinheim:Wiley-VHC.

Donaldson K, Borm PJ. 1998. The quartz hazard, a variable entity. Ann Occup Hyg 42:287-294.

Don Porto Carero A, Hoet PH, Verschaeve L, Schoeters G, Nemery B. 2001. Genotoxic effects of carbon black particles, diesel exhaust particles, and urban air particulates and their extracts on a human alveolar epithelial cell line (A549) and a human monocytic cell line (THP-1). Environ Mol Mutagen 37:155-163.

Enterline PE, Day R, Marsh GM. 1995. Cancers related to exposure to arsenic at a copper smelter. Occup Environ Med 52:28-32.

Eschbacher WL, Kullman GJ, Gomberg CC. 2000. Pulmonary effects of inhaled mineral dusts. In: Harris EL. Patty's Industrial Hygiene, Vol. 1. New York:Wiley. pp 89-130.

Fenech M. 2000. The in vitro micronucleus technique. Mutat Res 455:81-95.

Fenech M. 2007. The cytokinesis-block micronucleus cytome assay. Nat Protoc 2:1084-1104.

Fubini B. 1998. Surface chemistry and quartz hazard. Ann Occup Hyg 42:521-530.

Furukawa Y, Aizawa Y, Okada M, Watanabe M, Niitsuya M, Kotani M. 2002. Negative effects of photocopier toner on alveolar macrophages determined by in vitro magnetometric evaluation. Ind Health 40:214-221.

Gadhia P, Patel D, Solanki K, Tamakuwala D, Pithawala M. 2005. A preliminary cytogenetic and haematological study of photocopying machine operators. Ind J Occup Environ Med 9:22-25.

Gallardo MP, Romero P, Sanchez-Quevedo MC, Lopez-Caballero JJ. 1994. Siderosilicosis due to photocopier toner dust. Lancet 344:412-413.

Galun E, Rubinow A. 1989. Photocopier's papillitis. Lancet 2:929.

Giard DJ, Aaronson SA, Todaro GJ, Arnstein P, Kersey JH, Dosik H, Parks WP. 1997. In vitro cultivation of human tumors, establishment of cell lines derived from a series of solid tumors. J Natl Cancer Inst 51:1417-1423.

Gminski R, Mersch-Sundermann V. 2006. Evaluation of effects caused by exposure to toner dusts and emissions of laser printers and photocopiers to human health: Current state of knowledge. Umweltmed Forsch Prax 11:269-300.

Goud KI, Shankar B, Vijayashree B, Ahuja YR. 2001. DNA damage and repair studies in individuals working with photocopying machines. Int J Hum Genet 1:139-143.

Goud KI, Hasan Q, Balakrishna N, Prabhakar Rao K, Ahuja YR. 2004. Genotoxicity evaluation of individuals working with photocopying machines. Mutat Res 563:151-158.

Grimmer G, Jacob J, Naujack KW. 1997. Atmospheric emissions of polycyclic aromatic hydrocarbons in sampling areas of the German environmental specimen bank. Method for the precise measurement of gaseous and particle-associated polycyclic aromatic hydrocarbons in the sub-nanogram range using deuterated internal standards. Chemosphere 34:2213-2226.

He C, Morawska L, Taplin L. 2007. Particle emission characteristics of office printers. Environ Sci Technol 41:6039-6045.
Hetland RB, Schwarze PE, Johansen BV, Myran T, Uthus N, Refsnes M. 2001. Silica-induced cytokine release from A549 cells, importance of surface area versus size. Hum Exp Toxicol 20:46-55.

Hochella MF, Lower SK, Maurice PA, Penn RL, Sahai N, Sparks DL, Twining BS. 2008. Nanominerals, Mineral Nanoparticles, and Earth Systems. Science 5870:1631-1635.

IARC. 1990. Chromium, nickel, and welding. IARC Monogr Eval Carcinog Risks Hum 49.

IARC. 1996. Printing processes and printing inks, carbon black and some nitro compounds. IARC Monogr Eval Carcinog Risks Hum 65.

IARC. 1997. Silica, some silicates, coal dust and para-aramid fibrils. IARC Monogr Eval Carcinog Risks Hum 68.

Jungnickel F, Kubina A, Patrzek F. 2002. Content of heavy metals in toner powders. Umweltmed Forsch Prax 5:289-291.

Krause AW, Carley WW, Webb WW. 1984. Fluorescent Erythrosin B is preferable to trypan blue as a vital exclusion dye for mammalian cells in monolyer culture. J Histo Cytoxhem 32:1084-1090.

Kumaravel TS, Jha AN. 2006. Reliable comet assay measurements for detecting DNA damage induced by ionizing radiation and chemicals. Mutat Res 605:7-16.

Lechner JF, McClendon IA, LaVeck MA, Shamsuddin AM, Harris CC. 1983. Differential control by platelet factors of squamous differentiation in normal and malignant human bronchial epithelial cells. Cancer Res 43:5915-5921.

Lieber M, Smith B, Szakal A, Nelson-Rees W, Todaro G. 1976. A continuous tumor-cell line from a human lung carcinoma with properties of type II alveolar epithelial cells. Int J Cancer 17:62-70.

Lin GHY. 1999. Toxicological studies of a representative Xerox reprographic toner. Int J Toxicol 18:23-34.

Lin GHY, Mermelstein R. 1994. Acute toxicity studies of Xerox reprographic toners. J Am Coll Toxicol 3:2-20.

Löfroth G, Hefner E, Alfheim I, Moller M. 1980. Mutagenic activity in photocopiers. Science 209:1037-1039.

Mersch-Sundermann V. 2008. Pilotstudie, Evaluierung möglicher Beziehungen zwischen Emissionen aus Büromaschinen, insbesondere aus Fotokopierern und Laserdruckern, und Gesundheitsbeeinträchtigungen bzw. Gesundheitsschäden bei exponierten Büroangestellten. Bericht an das Bundesinstitut für Risikobewertung. Available at: http://www.bfr.bund.de/cm/252/pilotstudie_evaluierung moeglicher_beziehungen_zwischen_emissionen_aus_bueromaschinen_ abschlussbericht.pdf.

Mohr U, Ernst H, Roller M, Pott F. 2006. Pulmonary tumor types in wistar rats of the so-called 19-dust study. Exp Toxicol Pathol 58:13-20.

Möller A, Muhle H, Creutzenberg O, Bruch J, Rehn B, Blome H. 2004. Biological procedures for the toxicological assessment of toner dusts. Gefahrstoffe-Reinhaltung der Luft 64:13-20.

Morimoto Y, Kim H, Oyabu T, Hirohashi M, Nagatomo H, Ogami A, Yamato H, Higashi T, Tanaka I, Kasai T. 2005. Effect on longterm inhalation of toner on extracellular matrix in the lung of rats in vivo. Inhal Toxicol 17:153-159.

Nakadate T, Yamano Y, Adachi C, Kikuchi Y, Nishiwaki Y, Nohara M, Satoh T, Omae K. 2006. A cross sectional study of the respiratory health of workers handling printing toner dust. Occup Environ Med 63:244-249.

Nies E, Blome H, Brüggemann-Prieshoff H. 2000. Charakterisierung von Farbtonern und Emissionen aus Farbfotokopierern/Farblaserdruckern. Gefahrstoffe-Reinhaltung der Luft 60:435-441.

OECD, Organisation for Economic Co-operation and Development. 2007. OECD guideline for the testing of chemicals. Draft proposal for a new guideline 487: in vitro mammalian cell micronucleus test (MNvit). December 13, 2007 (Version 3):1-21.

Ott MG, Holder BB, Gordon HL. 1974. Respiratory cancer and occupational exposure to arsenicals. Arch Environ Health 29:250-255.

Ovrevik J, Låg M, Schwarze P, Refsnes M. 2004. p38 and Src-ERK1/2 pathways regulate crystalline silica-induced chemokine release in pulmonary epithelial cells. Toxicol Sci 81:480-490. 
Pott F, Roller M. 2005. Carcinogenicity study with nineteen granular dusts in rats. Eur J Oncol 10:249-281.

Rimal B, Greenberg AK, Rom WN. 2005. Basic pathogenetic mechanisms in silicosis, current understanding. Curr Opin Pulm Med 11:169-173.

Rödelsperger K, Roller M. 2003. Pulmonary carcinogenicity of granular bio-durable particles without significant specific toxicity (GBP), relevance for occupational safety. BIA-Report 7:175-199.

Rödelsperger K, Brückel B, Podhorsky S. 2006. Wirkungsbezogene Messung von Nanoteilchen. DGAUM, 46. Hannover:Jahrestagung.

Rosenkranz HS, McCoy EC, Sanders DR, Butler M, Kiriazides DK, Mermelstein R. 1980. Nitropyrens, isolation, identification and reduction of mutagenic impurities in carbon black and toners. Science 209:1039-1043.

Rybicki BA, Amend KL, Maliarik MJ, Ianuzzi MC. 2004. Photocopier exposure and risk of sarcoidosis in African-American sibs. Sarcoidosis Vasc Diffuse Lung Dis 21:49-55.

Schripp T, Wensing M, Uhde E, Salthammer T, He C, Morawska L. 2008. Evaluation of ultrafine particle emissions from laser printers using emission test chambers. Environ Sci Technol 42:4338-4343.

Schwerdtle T, Hartwig A. 2006. Bioavailability and genotoxicity of soluble and particulate nickel compounds in cultured human lung cells. Mater Sci Eng Technol 37:521-525.

Seilkop SK, Oller AR. 2003. Respiratory cancer risks associated with low-level nickel exposure, an integrated assessment based on animal, epidemiological, and mechanistic data. Regul Toxicol Pharm 37:173-190.

Slesinski RS, Turnbull D. 2008. Chronic inhalation exposure of rats for up to 104 weeks to a non-carbon-based magnetite photocopying toner. Int J Toxicol 27:427-439.

Singh N, McCoy MT, Tice RR, Schneider EL. 1988. A simple technique for quantitation of low levels of DNA damage in individual cells. Exp Cell Res 175:184-191.

Skoner DP, Hodgson MJ, Doyle WJ. 1990. Laser-printer rhinitis. N Engl J Med 322:1323.

Stelting HJ. 2006. Illness through toner-Experiences with a nanopathology. Umweltmed Forsch Prax 11:269-300.

Straif K, Benbrahim-Tallaa L, Baan R, Grosse Y, Secretan B, El Ghissassi F, Bouvard V, Guha N, Freeman C, Galichet L, Cogliano V. 2009. WHO international agency for research on cancer monograph working group: A review of human carcinogens Part C, metals, arsenic, dusts, and fibres. Lancet Oncol 10:453-454.
Suralles J, Xamena N, Creus A, Catalan J, Norppa H, Marcos R. 1995. Induction of micronuclei by five pyrethroid insecticides in whole blood and isolated human lymphocyte culture. Mutat Res 341:169-184.

Tencati JR, Novey HS. 1983. Hypersensitivity angiitis caused by fumes from heat-activated photocopy paper. Ann Intern Med 98:320322.

Tice R, Agurell E, Anderson D, Burlinson B, Hartmann A, Kobayashi H, Miyamae Y, Rojas E, Ryu C, Sasaki Y. 2000. Single cell gel/ comet assay, guidelines for in vitro and in vivo genetic toxicology testing. Environ Mol Mutagen 35:206-221.

Totsuka Y, Higuchi T, Imai T, Nishikawa A, Nohmi T, Kato T, Masuda S, Kinae N, Hiyoshi K, Ogo S, Kawanishi M, Yagi T, Ichinose T, Fukumori N, Watanabe M, Sugimura T, Wakabayashi K. 2009. Genotoxicity of nano/microparticles in in vitro micronuclei, in vivo comet and mutation assay systems. Part Fibre Toxicol 6:23.

Umegaki K, Fenech M. 2000. Cytokinesis-block micronucleus assay in WIL2-NS cells, a sensitive system to detect chromosomal damage induced by reactive oxygen species and activated human neutrophils. Mutagen 15:261-269.

Wang JJ, Sanderson BJ, Wang H. 2007. Cytotoxicity and genotoxicity of ultrafine crystalline $\mathrm{SiO}_{2}$ particulate in cultured human lymphoblastoid cells. Environ Mol Mutagen 48:151-157.

Wensing M, Schripp T, Uhde E, Salthammer T. 2008. Ultra-fine particles release from hardcopy devices: Sources, real-room measurements and efficiency of filter accessories. Sci Total Environ 407:418-427.

Wieriks J. 1996. Photocopier toner dust and lung disease. Lancet 348:518-519.

Wittczak T, Walusiak J, Ruta U, Palczynski C. 2003. Occupational asthma and allergic rhinitis due to xerographic toner. A case of occupational asthma and rhinitis caused by xerographic toner, confirmed by specific bronchial provocation. Allergy 58:957.

Yassi A, Warrington RJ. 1988. Allergic eye reaction to photocopier chemicals. J Occup Med 30:457-458.

Zina AM, Fanan E, Bundino S. 2000. Allergic contact dermatitis from formaldehyde and quaternium-15 in photocopier toner. Contact Dermatitis 43:241-242.

Accepted by-

D. DeMarini 